\title{
The Lawyer as Friend: The Moral Foundations of the Lawyer-Client Relation
}

\section{Citation}

Charles Fried, The Lawyer as Friend: The Moral Foundations of the Lawyer-Client Relation, 85 Yale L.J. 1060 (1976).

\section{Permanent link}

http://nrs.harvard.edu/urn-3:HUL.InstRepos:23903316

\section{Terms of Use}

This article was downloaded from Harvard University's DASH repository, and is made available under the terms and conditions applicable to Other Posted Material, as set forth at http:// nrs.harvard.edu/urn-3:HUL.InstRepos:dash.current.terms-of-use\#LAA

\section{Share Your Story}

The Harvard community has made this article openly available.

Please share how this access benefits you. Submit a story.

Accessibility 


\title{
The Lawyer as Friend: The Moral Foundations of the Lawyer-Client Relation*
}

\author{
Charles Fried ${ }^{\dagger}$
}

\author{
Advocatus sed non ladro, \\ Res miranda populo.... \\ Medieval anthem \\ honoring St. Ives
}

Can a good lawyer be a good person? The question troubles lawyers and law students alike. They are troubled by the demands of loyalty to one's client and by the fact that one can win approval as a good, maybe even great, lawyer even though that loyalty is engrossed by overprivileged or positively distasteful clients. How, they ask, is such loyalty compatible with that devotion to the common good characteristic of high moral principles? And whatever their views of the common good, they are troubled because the rvillingness of lawyers to help their clients use the law to the prejudice of the weak or the innocent seems morally corrupt. The lawyer is conventionally seen as a professional devoted to his client's interests and as authorized, if not in fact required, to do some things (though not anything) for that client which he would not do for himself. ${ }^{1}$ In this essay I consider the com-

* Copyright (C) 1976 by Charles Fried. This essay is part of a larger work on right and wrong, supported by the National Science Foundation under grant number SOC7513506. Research assistance and suggestions were provided by Dan Polster and Jerrold Tannenbaum, students at the Harvard Law School. I am grateful for the comments of Gary Bellow, Sissela Bok, Alan Dershowitz, Philip Heymann, Andrew Kaufman, Robert Keeton, Thomas Nagel, Charles Nesson, Albert Sacks, and David Shapiro. I am especially grateful to the editors of the Yale Law Journal for their understanding, help, and encouragement. I wonder if any of them agree with what I say here. The National Science Foundation, of course, underwrites only the effort, not the conclusion.

$\dagger$ Professor of Law, Harvard University.

1. See, e.g., J. Auerbach, Unequal Justice (1976); M. GreeN, The Other Government (1975).

Lord Brougham stated the traditional view of the lawyer's role during his defense of Queen Caroline:

[A]n advocate, in the discharge of his duty, knows but one person in all the world, and that person is his client. To save that client by all means and expedients, and at all hazards and costs to other persons, and, among them, to himself, is his first and only duty; and in performing this duty he must not regard the alarm, the torments, the destruction which he may bring upon others. Separating the duty of a patriot from that of an adrocate, he must go on reckless of consequences, though it should be his unhappy fate to involve his country in confusion.

2 Trial of QuefN Caroline 8 (J. Nightingale ed. 1821). A sharply contrasting view was held by law professors at the University of Havana who said that "the first job of a 
patibility between this traditional conception of the lawyer's role and the ideal of moral purity-the ideal that one's life should be lived in fulfillment of the most demanding moral principles, and not just barely within the law. So I shall not be particularly concerned with the precise limits imposed on the lawyer's conduct by positive rules of law and by the American Bar Association's Code of Professional Responsibility ${ }^{2}$ except as these provide a background. I assume that the lawyer observes these scrupulously. My inquiry is one of morals: Does the lawyer whose conduct and choices are governed only by the traditional conception of the lawyer's role, which these positive rules reflect, lead a professional life worthy of moral approbation, worthy of respect-ours and his own?

\section{The Challenge to the Traditional Conception}

\section{A. The Two Criticisms}

Two frequent criticisms of the traditional conception of the lawyer's role attack both its ends and its means. First, it is said that the ideal of professional loyalty to one's client permits, even demands, an allocation of the lawyer's time, passion, and resources in ways that are not always maximally conducive to the greatest good of the greatest number. ${ }^{3}$ Interestingly, this criticism is leveled increasingly against doctors ${ }^{4}$ as well as larvyers. Both professions affirm the principle that the professional's primary loyalty is to his client, ", his patient. A "good" lawyer will lavish energy and resources on his existing client, even if it can be shown that others could derive greater benefit from them. The professional ideal authorizes a care for the client and the patient which

revolutionary lawyer is not to argue that his client is innocent, but rather to determine if his client is guilty and, if so, to seck the sanction which will best rehabilitate him." Berman, The Cuban Popular Tribunals, 69 Colux. L. Rev. 1317, 1341 (1969). And a Bulgarian attorney has been quoted as saying, "In a Socialist state there is no division of duty between the judge, prosecutor and defense counsel . . . the defense must assist the prasecution to find the objective truth in a case." J. Kaplan, Criminill Justice: Introductory Cases AND Materials 264-65 (1973).

2. The American Bar Association approved a revised Code of Professional Responsibility in 1969. In part that revision was a response to the criticism that the legal profession, by failing to make legal services more widely arailable, had not met its public responsibilities. J. Auerbach, supra note 1, at 285-86. See also Preface, ABA Code of Professional Responsibility.

3. See M. GREEN, supra note 1 , at 268-69, 285-89.

4. See V. Fuchs, Who Shall LIVE? 60 (1974); Havighurst \& Blumstein, Coping With Quality/Cost Trade-Offs in Medical Care: The Role of PSROs, 70 Nw. U. L. REv. 6, 25.28 (1975). But see Fried, Equality and Rights in Medical Care, 6 Hastings Center REP. 29, 33-34 (1976).

5. See aba Code of Professional Responsibility Canon 7. 
exceeds what the efficient distribution of a scarce social resource (the professional's time) would dictate.

That same professional ideal has little or nothing to say about the initial choice of clients or patients. Certainly it is laudable if the doctor and lawyer choose their clients among the poorest or sickest or most dramatically threatened, but the professional ideal does not require this kind of choice in any systematic way-the choice of client remains largely a matter of fortuity or arbitrary choice. But once the client has been chosen, the professional ideal requires primary loyalty to the client whatever his need or situation. Critics contend that it is wasteful and immoral that some of the finest talent in the legal profession is devoted to the intricacies of, say, corporate finance or elaborate estate plans, while important public and private needs for legal services go unmet. The immorality of this waste is seen to be compounded when the clients who are the beneficiaries of this lavish attention use it to avoid their obligations in justice (if not in law) to society and to perpetuate their (legal) domination of the very groups whose greater needs these lawyers should be meeting. ${ }^{\circ}$

The second criticism applies particularly to the lawyer. It addresses not the misallocation of scarce resources, which the lawyer's exclusive concern with his client's interests permits, but the means which this loyalty appears to authorize, tactics which procure advantages for the client at the direct expense of some identified opposing party. Examples are discrediting a nervous but probably truthful complaining witness ${ }^{7}$ or taking advantage of the need or ignorance of an adversary in a negotiation. This second criticism is, of course, related to the first, but there is a difference. The first criticism focuses on a social harm: the waste of scarce resources implicit in a doctor caring for the hearts of the sedentary managerial classes or a lawyer tending to the estates and marital difficulties of the rich. The professional is accused of failing to confer benefits wisely and efficiently. By the second criticism the lawyer is accused not of failing to benefit the appropriate, though usually unidentified, persons, but of harming his identified adversary. ${ }^{8}$

6. For a description of the growth of such criticisms, see J. AuERBACH, supra note I, at $275-88$.

7. For a defense of an attorney's use of such tactics, see M. FreEdMan, LAwYers' Ethics in an Adversary System 43-49 (1975). See also Curtis, The Ethics of Advocacy, 4 STAN. L. REv. 3 (1951).

8 . The point really carries further than the distinction between benefit and harm. In the former case, though some particular person may have benefited had the distribution been efficient, it does not seem correct to say that for that reason this person had a right to the benefit which he was denied, or that this person was wronged by not receiving the benefit. Individuals do not acquire rights under policies which are dictated 


\section{B. Examples}

Consider a number of cases which illustrate the first criticism: A doctor is said to owe a duty of loyalty to his patient, but how is he to react if doing his very best for his patient would deplete the resources of the patient's family, as in the case of a severely deformed baby who can only be kept alive through extraordinarily expensive means? Should a doctor prescribe every test of distinct but marginal utility for every patient on public assistance, even if he knows that in the aggregate such a policy will put the medical care system under intolerable burdens?? ${ }^{?}$ Should he subject his patients to prudent testing of new remedies because he knows that only in this way can medicine make the strides that it has in the past? ${ }^{10}$

These problems are analogous to problems which are faced by the lawyer. The lawyer who advises a client how to avoid the effects of a tax or a form of regulation, though it is a fair tax or a regulation in the public interest, is facing the same dilemma and resolving it in favor of his client. So does the public defender who accedes to his client's demands and takes a "losing" case to trial, thereby wasting court time and depleting the limited resources of his organization. We

purely by considerations of efficiency. See generally Dworkin, Hard Cases, 88 Harv. L. REv. 1057, 1058-78 (1975).

Professor Anscombe makes the following suggestive argument: If saving the life of one patient requires a massive dose of a drug that could be divided up and used to save five other people, not one of those five can claim that he has been wronged, that the smaller dose of the drug was owed to him.

Yet all can reproach me if $I$ gave it to none. It was therc, ready to supply human need, and human need was not supplied. So any one of them can say: you ought to have used it to help us who needed it; and so all are wronged. But if it was used for somcone, as much as he needed it to keep him alive, no one has any ground for accusing me of having wronged himself.-Why, just because he was one of five who could have been saved, is he wronged in not being saved, if someone is supplied with it who needed it? What is his claim, except the claim that what was needed go to him rather than be wasted? But it was not wasted. So he was not wronged. So who was wronged? And if no one was wronged, what injury did I do?

....

I do not mean that 'because they are morc' isn't a good reason for helping these and not that onc, or these rather than those. It is a perfectly intelligible reason. But it doesn't follow from that that a man acts badly if he docsn't make it his reason. He acts badly if human need for what is in his power to give docsn't work in him as a reason. He acts badly if he chooses to rescuc rich people rather than poor ones, having ill regard for the poor ones because they are poor. But he doesn't act badly if he uses his resources to save $\mathrm{X}$, or $\mathrm{X}, \mathrm{Y}$ and $\mathrm{Z}$, for no bad reason, and is not affected by the consideration that he could save a larger number of people. For, once morc: who can say he is wronged? And if no one is wronged, how does the rescuer commit any wrong?

Anscombe, Who is Wronged?, 5 OxForo Rev. 16, 16-17 (1967) (emphasis in original).

9. See generally V. Fuchs, supra note 4, at 94-95; Fried, Rights and Health CareBeyond Equily and Efficiency, 293 New England J. Medicine 241, 244 (1975).

10. For discussions of this dilemma, see A. Cochrane, Effectiveness and Efficiency (1972); C. Fried, Medicil Experimentition: Personal Integrity and Social Policy (1974). 
tolerate and indeed may applaud the decision of a lawyer who vigorously defends a criminal whom he believes to be guilty and dangerous. ${ }^{11}$ And I for one think that a lawyer who arranges the estate of a disagreeable dowager or represents one of the parties in a bitter matrimonial dispute must be as assiduous and single-minded in fulfilling his obligation to that client as the lawyer who is defending the civil liberties case of the century.

Illustrative of the second criticism (doing things which are offensive to a particular person) are familiar situations such as the following: In a negotiation it becomes clear to the lawyer for the seller that the buyer and his lawyer mistakenly believe that somebody else has already offered a handsome price for the property. The buyer asks the seller if this is true, and the seller's lawyer hears his client give an ambiguous but clearly encouraging response. ${ }^{12}$ Another classic case is the interposition of a technical defense such as the running of the statute of limitations to defeat a debt that the client admits he owes. ${ }^{13}$

There is another class of cases which does not so unambiguously involve the lawyer's furthering his client's interests at the direct expense of some equally identified, concrete individual, but where furthering those interests does require the lawyer to do things which are personally offensive to him. The conventional paradigms in the casuistic literature deal with criminal defense lawyers who are asked improper questions by the trial judge ("Your client doesn't have a criminal record, does he?" or "Your client hasn't offered to plead guilty to a lesser offense, has he?"), a truthful answer to which would be damningly prejudicial to the client, but which the lawyer cannot even refuse to answer without running the risk of creating the same prejudice. There are those who say the lawyer must lie in defense of his client's interests even though lying is personally and professionally offensive to him. ${ }^{1 \pm}$ The defense lawyer who cross-examines a complaining

11. See M. Friedman, supra note 7, at 43-49.

12. DR 7-102(A)(5) of the Code of Professional Responsibility states that a lawyer shall not knowingly make a false statement of law or fact in his representation of a client. The issue is how to apply this admonition in the context of negotiation, where deception is commonplace. See Mr. Meltsner \& P. Schrag, Public Intrrest Advocacr: Materials for Clinical Legal Education 231-39 (1974).

13. For a striking example, see Zabella v. Pakel, 242 F.2d 452 (7th Cir. 1957), where the debtor asserting the technical defenses was a savings and loan association president, and the creditor was a man who had worked for him as a carpenter and had lent him money in earlier, less fortunate days.

14. Although Charles Curtis explicitly denounces lying to the court, his observation that the propriety of lying might depend on whether the question is asked "by someone who has a right to ask it" at least implies a possible qualification in the case of improper questioning by the court. Curtis, supra note 7. at 7-9. Monroc Frecdman does not specifically address this problem, but his argument that an attorney's duty to safeguard 
rape victim (whom he knows to be telling the truth) about her chastity or lack thereof in order to discredit her accusing testimony faces a similar moral difficulty. In some respects these cases might be taken to illustrate both principal criticisms of the traditional conception. On the one hand, there is harm to society in making the choice to favor the client's interests: a dangerous criminal may escape punishment or an appropriately heavy sentence. On the other hand, this social harm is accomplished by means of acting towards another human being-the judge, the complaining witness-in ways that seem demeaning and dishonorable.

\section{The Lawyer as Friend}

\section{A. The Thesis}

In this essay I will consider the moral status of the traditional conception of the professional. The two criticisms of this traditional conception, if left unanswered, will not put the lawyer in jail, but they will leave him without a moral basis for his acts. The real question is whether, in the face of these two criticisms, a decent and morally sensitive person can conduct himself according to the traditional conception of professional loyalty and still believe that what he is doing is morally worthwhile.

It might be said that anyone whose conscience is so tender that he cannot fulfill the prescribed obligations of a professional should not undertake those obligations. He should not allow his moral scruples to operate as a trap for those who are told by the law that they may expect something more. But of course this suggestion merely pushes the inquiry back a step. We must ask then not how a decent lawyer may behave, but whether a decent, ethical person can ever be a lawyer. Are the assurances implicit in assuming the role of lawyer such that an honorable person would not give them and thus would not enter the profession? And, indeed, this is a general point about an argument from obligation: ${ }^{15}$ It may be that the internal logic of a particular obligation demands certain forms of conduct (e.g., honor among

the attorney-client privilege requires the attorney to introduce his client's perjurious testimony would seem to extend to this situation. M. FreEdMaN, supra note 7, at 27.41. Cf. ABA Comm. on Professional Ethics, Opinions No. 287 (1967) (if attorney for defendant learns of previous criminal record through his communications with his client, he has no duty to correct misapprehension on part of court that client has no record).

15. That one assumes obligations to persons which cannot always be overridden by the bencfits which would accrue from aiding some third person is a standard objection to utilitarianism. See, e.g., W. Ross, The Rigir aND the Good 17-19 (1930). 
thieves), but the question remains whether it is just and moral to contract such obligations.

I will argue in this essay that it is not only legally but also morally right that a lawyer adopt as his dominant purpose the furthering of his client's interests-that it is right that a professional put the interests of his client above some idea, however valid, of the collective interest. I maintain that the traditional conception of the professional role expresses a morally valid conception of human conduct and human relationships, that one who acts according to that conception is to that extent a good person. Indeed, it is my view that, far from being a mere creature of positive law, the traditional conception is so far mandated by moral right that any advanced legal system which did not sanction this conception would be unjust.

The general problem raised by the two criticisms is this: How can it be that it is not only permissible, but indeed morally right, to favor the interests of a particular person in a way which we can be fairly sure is either harmful to another particular individual or not maximally conducive to the welfare of society as a whole ${ }^{16}$

The resolution of this problem is aided, I think, if set in a larger perspective. Charles Curtis made the perspicacious remark that a lawyer may be privileged to lie for his client in a way that one might lie to save one's friends or close relatives. ${ }^{17}$ I do not want to underwrite the notion that it is justifiable to lie even in those situations, but there is a great deal to the point that in those relations-friendship, kinship-we recognize an authorization to take the interests of particular concrete persons more seriously and to give them priority over the interests of the wider collectivity. One who provides an expensive education for his own children surely cannot be blamed because he does not use these resources to alleviate famine or to save lives in some distant land. Nor does he blame himself. Indeed, our intuition that an individual is authorized to prefer identified persons standing close to him over the abstract interests of humanity finds its sharpest expression in our sense that an individual is entitled to act with something less than impartiality to that person who stands closest to him-the person that he is. There is such a thing as selfishness to be sure, yet no reasonable

16. I have discussed this problem elsewhere. C. FRied, An Anatomy of Values 207-36 (1970); C. FrIED, supra note 10, at 132-37. Cf. Schelling, The Life You Save May Be Your Own, in Problems in Public Expenditure Axalysis 127, 129-30 (S. Chase ed. 1968) (also discussing our greater concern for known, as opposed to unknown, individuals).

17. Curtis, supra note 7 , at 8 . Analogizing the lawyer to a friend raises a range of problems upon which I shall not touch. These have to do with the lawyer's benevolent and sometimes not so benevolent tyranny over and imposition on his client, secmingly authorized by the claim to be acting in the client's interests. Domineering paternalism is not a normal characteristic of friendship. This point is due to Jay Katz. 
morality asks us to look upon ourselves as merely plausible candidates for the distribution of the attention and resources which we command, plausible candidates whose entitlement to our own concern is no greater in principle than that of any other human being. Such a doctrine may seem edifying, but on reflection it strikes us as merely fanatical.

This suggests an interesting way to look at the situation of the lawyer. As a professional person one has a special care for the interests of those accepted as clients, just as his friends, his family, and he himself have a very general claim to his special concern. But I concede this does no more than widen the problem. It merely shows that in claiming this authorization to have a special care for my clients I am doing something which $I$ do in other contexts as well.

\section{B. The Utilitarian Explanation}

I consider first an argument to account for fidelity to role, for obligation, made most elaborately by the classical utilitarians, Mill ${ }^{18}$ and Sidgwick. ${ }^{19}$ They argued that our propensity to prefer the interests of those who are close to us is in fact perfectly reasonable because we are more likely to be able to benefit those people. Thus, if everyone is mainly concerned with those closest to him, the distribution of social energies will be most efficient and the greatest good of the greatest number will be achieved. The idea is that the efforts I expend for my friend or my relative are more likely to be effective because I am more likely to know what needs to be done. I am more likely to be sure that the good I intend is in fact accomplished. One might say that there is less overhead, fewer administrative costs, in benefiting those nearest to us. I would not want to ridicule this argument, but it does not seem to me to go far enough. Because if that were the sole basis for the preference, then it would be my duty to determine whether my efforts might not be more efficiently spent on the collectivity, on the distant, anonymous beneficiary. But it is just my point that this is an inquiry we are not required, indeed sometimes not even authorized, to make. When we decide to care for our children, to assure our own comforts, to fulfill our obligations to our clients or patients, we do not do so as a result of a cost-benefit inquiry which takes into account the ease of producing a good result for our friends and relations.

Might it not be said, however, that the best means of favoring the

18. Mill, Utilitarianism, in The Philosophy of John Stuart Mill 321, 342-44 (M. Cohen ed. 1961).

19. H. Sidgwick, The MEthods of Ethics 252 (7th ed. 1907). 
abstract collectivity is in certain cases not to try to favor it directly but to concentrate on those to whom one has a special relation? This does not involve tricking oneself, but only recognizing the limitations of what an individual can do and know. But that, it seems to me, is just Mill's and Sidgwick's argument all over again. There is no trickery involved, but this is still a kind of deliberate limitation of our moral horizon which leaves us uncomfortable. Do I know in a particular case whether sticking to the narrow definition of my role will in that case further the good of all? If I know that it will not further the general good, then why am I acting as the role demands? Is it to avoid setting a bad example? But for whom? I need not tell others-whether I tell or not could enter into my calculation. For myself then? But that begs the question, since if short-circuiting the role-definition of my obligation and going straight for the general good is the best thing to do in that case, then the example I set myself is not a bad example, but a good example. In short, I do not see how one can at the same time admit that the general good is one's only moral standard, while steadfastly hewing to obligations to friends, family, and clients. What we must look for is an argument which shows that giving some degree of special consideration to myself, my friends, my clients is not merely instrumentally justified (as the utilitarians would argue) but to some degree intrinsically so. ${ }^{20}$

I think such an argument can be made. Instead of speaking the language of maximization of value over all of humanity, it will speak the language of rights. The stubborn ethical datum affirming such a preference grows out of the profoundest springs of morality: the concepts of personality, identity, and liberty.

\section{G. Self, Friendship, and Justice}

Consider for a moment the picture of the human person that would emerge if the utilitarian claim were in fact correct. It would mean that in all my choices I must consider the well-being of all humanityactual and potential-as the range of my concern. Moreover, every actual or potential human being is absolutely equal in his claims upon me. Indeed, I myself am to myself only as one of this innumerable multitude. And that is the clue to what is wrong with the utilitarian vision. Before there is morality there must be the person. We must attain and maintain in our morality a concept of personality such that

20. See generally D. LYons, Forms AND LmMits OF UtILITARIANISM (1965); J. SMART \& B. Williams, Utilitarianism: For and Against (1973); Harrod, Ulilitarianism Revised, 45 Mind 137 (1936); Mabbott, Punishment, 48 Mind 152 (1939). 
it makes sense to posit choosing, valuing entities-free, moral beings. But the picture of the moral universe in which my own interests disappear and are merged into the interests of the totality of humanity is incompatible with that, ${ }^{21}$ because one wishes to develop a conception of a responsible, valuable, and valuing agent, and such an agent must first of all be dear to himself. It is from the kernel of individuality that the other things we value radiate. The Gospel says we must love our neighbor as ourselves, and this implies that any concern for others which is a human concern must presuppose a concern for ourselves. ${ }^{22}$ The human concern which we then show others is a concern which first of all recognizes the concrete individuality of that other person just as we recognize our own.

It might be objected that the picture I sketch does not show that each individual, in order to maintain the integral sense of himself as an individual, is justified in attributing a greater value to his most essential interests than he ascribes to the most essential interests of all other persons. Should not the individual generalize and attribute in equal degree to all persons the value which he naturally attributes to himself? I agree with those who hold that it is the essence of morality for reason to push us beyond inclination to the fair conclusion of our

21. See generally C. Fried, AN Anatomy of Values, 203-06; Rawls, The Independence of Moral Theory, 48 AM. PHIL. Ass'N 17.20 (1975) (Kantian theory, as compared to utilitarianism, takes seriously basic moral fact of primacy of notion of individual personality).

22. ... It is written (Lev. xix. 18, Matth. xxii. 39); Thou shalt love thy neighbor

(Lev. lac. cit.,-friend) as thyself. Whence it seems to follow that man's love for himself is the model of his love for another. But the model exceeds the copy. Therefore, out of charity, a man ought to love himself more than his neighbor.

....

We must, therefore, say that, even as regards the affection we ought to love one neighbor more than another. The reason is that, since the principle of love is God, and the person who loves, it must needs be that the affection of love increases in proportion to the nearness to one or the other of those principles.

....

... As stated above... we ought out of charity to love those who are more closely united to us more, both because our love for them is more intense, and because there are more reasons for loving them. . . .

Accordingly we must say that friendship among blood relations is based upon their connection by natural origin, the friendship of fellow-citizens on their civic fellowship, and the friendship of those who are fighting side by side on the comradeship of battle. Wherefore in matters pertaining to nature we should love our kindred most, in matters concerning relations between citizens, we should prefer our fellow-citizens, and on the battlefield our fellow-soldiers. ...

…

If however we compare union with union, it is evident that the union arising from natural origin is prior to, and more stable than, all others, because it is something affecting the very substance, whereas other unions supervene and may cease altogether.

II Thomas Aquinas, Suma Theologra 1297-1301 (Fathers of the English Dominican Province trans. 1947). 
premises. ${ }^{23}$ It is a fair conclusion that as my experience as a judging, valuing, choosing entity is crucial to me, I must also conclude that for other persons their own lives and desires are the center of their universes. If morality is transcendent, it must somehow transcend particularity to take account of this general fact. I do not wish to deny this. On the contrary, my claim is that the kind of preference which an individual gives himself and concrete others is a preference which he would in exactly this universalizing spirit allow others to exhibit as well. It is not that I callously overlook the claim of the abstract individual, but indeed I would understand and approve were I myself to be prejudiced because some person to whom I stood in a similar situation of abstraction preferred his own concrete dimensions.

Finally, the concreteness which is the starting point of my own moral sensibility, the sense of myself, is not just a historical, biographical fact. It continues to enter into and condition my moral judgments because the effects which I can produce upon people who are close to me are qualitatively different from those produced upon abstract, unknown persons. My own concreteness is important not only because it establishes a basis for understanding what I and what all other human beings might be, but because in engaging that aspect of myself with the concrete aspects of others, I realize special values for both of us. Quite simply, the individualized relations of love and friendship (and perhaps also their opposites, hatred and enmity) have a different, more intense aspect than do the cooler, more abstract relations of love and service to humanity in general. The impulse I describe, therefore, is not in any sense a selfish impulse. But it does begin with the sense of self as a concrete entity. Those who object to my thesis by saying that we must generalize it are not wholly wrong; they merely exaggerate. Truly I must be ready to generalize outward all the way. That is what justice consists of. But justice is not all of morality; there remains a circle of intensity which through its emphasis on the particular and the concrete continues to reflect what I have identified as the source of all sense of value-our sense of self.

Therefore, it is not only consonant with, but also required by, an ethics for human beings that one be entitled first of all to reserve an area of concern for oneself and then to move out freely from that area if one wishes to lavish that concern on others to whom one stands in concrete, personal relations. Similarly, a person is entitled to enjoy

23. See G. Warnock, The Object of Morality 79-80 (1971); Nagel, Book Review, 85 YALE L.J. 136, 140 (1975). 
this extra measure of care from those who choose to bestow it upon him without having to justify this grace as either just or efficient. We may choose the individuals to whom we will stand in this special relation, or they may be thrust upon us, as in family ties. Perhaps we recognize family ties because, after all, there often has been an element of choice, but also because-by some kind of atavism or superstitionwe identify with those who share a part of our biological natures.

In explicating the lawyer's relation to his client, my analogy shall be to friendship, where the freedom to choose and to be chosen expresses our freedom to hold something of ourselves in reserve, in reserve even from the universalizing claims of morality. These personal ties and the claims they engender may be all-consuming, as with a close friend or family member, or they may be limited, special-purpose claims, as in the case of the client or patient. ${ }^{24}$ The special-purpose claim is one in which the beneficiary, the client, is entitled to all the special consideration within the limits of the relationship which we accord to a friend or a loved one. It is not that the claims of the client are less intense or demanding; they are only more limited in their scope. After all, the ordinary concept of friendship provides only an analogy, and it is to the development of that analogy that I turn.

\section{Special-Purpose Friends}

How does a professional fit into the concept of personal relations at all? $\mathrm{He}$ is, $\mathrm{I}$ have suggested, a limited-purpose friend. A lawyer is a friend in regard to the legal system. He is someone who enters into a personal relation with you-not an abstract relation as under the concept of justice. That means that like a friend he acts in your interests, not his own; or rather he adopts your interests as his own. I would call that the classic definition of friendship. To be sure, the lawyer's range of concern is sharply limited. But within that limited

24. This argument is, of course, just a fragment which must be fitted into a larger theory. This larger theory would have to explain, among other things, what the precise contents of the various personal roles might be and how conflicts between personal roles are to be resolved. My later discussion of permissible and impermissible tactics in legal representation deals with this conflict in one context. A complete theory would also have to spell out the relation between personal roles and duties to the larger collectivity. These latter duties to man in the abstract as opposed to concrete persons are the subject of principles of justice. I have no doubt that such abstract duties exist and that they can be very demanding. Roughly, I would adopt something like the principles put forward in J. R.IWLS, A Theorx of JUSTICE 54-117 (1971). I would require, however, that these principles of justice leave sufficient scope for the free definition and inviolability of personal relations-to a greater extent perhaps than Rawls allows. These systematic concerns are the subject of a larger work from which the present essay is drawn. The relation of principles of justice to other aspects of right and wrong is a principal concern of that larger work. 
domain the intensity of identification with the client's interests is the same. It is not the specialized focus of the relationship which may make the metaphor inapposite, but the way in which the relation of legal friendship comes about and the one-sided nature of the ensuing "friendship." But I do insist upon the analogy, for in overcoming the arguments that the analogy is false, I think the true moral foundations of the lawyer's special role are illuminated and the utilitarian objections to the traditional conception of that role overthrown.

\section{The Professional Role as Socially Defined: The Content of the Relation}

The claims that are made on the doctor or lawyer are made within a social context and are defined, at least in part, by social expectations. Most strikingly, in talking about friendship the focus of the inquiry is quite naturaily upon the free gift of the donor; yet in professional relationships it is the recipient's need for medical or legal aid which defines the relationship. So the source of the relationship seems to be located at the other end, that of the recipient. To put this disquiet another way, we might ask how recognizing the special claims of friendship in any way compels society to allow the doctor or the lawyer to define his role on the analogy of those claims. Why are these people not like other social actors designated to purvey certain, perhaps necessary, goods? Would we say that one's grocer, tailor, or landlord should be viewed as a limited-purpose friend? Special considerations must be brought forward for doctors and lawyers. ${ }^{25}$

A special argument is at hand in both cases. The doctor does not minister just to any need, but to health. He helps maintain the very physical integrity which is the concrete substrate of individuality. To be sure, so does a grocer or landlord. But illness wears a special guise: it appears as a critical assault on one's person. The needs to which the doctor ministers usually are implicated in crises going to one's concreteness and individuality, and therefore what one looks for is a kind of ministration which is particularly concrete, personal, individualized. Thus, it is not difficult to see why I claim that a doctor is a friend, though a special purpose friend, the purpose being defined by the special needs of illness and crisis to which he tends.

25. This question might be more troubling in a socialist system in which the profit motive is theoretically subordinated to the service of the general good. But my argument is that the needs for whith lawyers and doctors provide are significantly different in kind from those met by other economic agents. Therefore, my argument about doctors and lawyers should be general enough to apply in either a free enterprise or a socialist system. 
But what, then, of the lawyer? Friendship and kinship are natural relations existing within, but not defined by, complex social institutions. Illness too is more a natural than social phenomenon. The response here requires an additional step. True, the special situations -legal relations or disputes-in which the lawyer acts as a limitedpurpose friend are themselves a product of social institutions. But it does not follow that the role of the lawyer, which is created to help us deal with those social institutions, is defined by and is wholly at the mercy of the social good. We need only concede that at the very least the law must leave us a measure of autonomy, whether or not it is in the social interest to do so. Individuals have rights over and against the collectivity. ${ }^{26}$ The moral capital arising out of individuals' concrete situations is one way of expressing that structure of rights, or at least part of it. It is because the law must respect the rights of individuals that the law must also create and support the specific role of legal friend. For the social nexus-the web of perhaps entirely just institutions-has become so complex that without the assistance of an expert adviser an ordinary layman cannot exercise that autonomy which the system must allow him. Without such an adviser, the law would impose constraints on the lay citizen (unequally at that) which it is not entitled to impose explicitly. Thus, the need which the lawyer serves in his special-purpose friendship may not be, as in the case of the doctor, natural, pre-social. Yet it is a need which has a moral grounding analogous to the need which the physician serves: the need to maintain one's integrity as a person. When I say the lawyer is his client's legal friend, "I mean the lawyer makes his client's interests his own insofar as this is necessary to preserve and foster the client's autonomy within the law. This argument does not require us to assume that the law is hostile to the client's rights. All we need to assume is that even a system of law which is perfectly sensitive to personal rights would not work fairly unless the client could claim a professional's assistance in realizing that autonomy which the law recognizes.

\section{The Asymmetry of Motive and Duty: The Form of the Relation}

The institutional origin of the lawyer-client relationship is not its only characteristic which suggests that the analogy to natural friendship

26. For a recent forceful statement of this conception of rights, see Dworkin, Taking Rights Seriously, in Is LAW DEAD? 168 (E. Rostow ed. 1971). See generally Dworkin, The Original Position, 40 U. CHI. L. Rev. 500, 522-28 (1973). 
is vulnerable. In natural friendship the ideal relation is reciprocal; in legal friendship it is not. The lawyer is said to be the client's friend insofar as he is devoted to his client's interests, but it is no part of the ideal that the client should have any reciprocal devotion to the interests of his lawyer. Furthermore, I have argued that our right to be a friend to whomever we choose is a product of our individual autonomy. But in legal friendship the emphasis has been on the autonomy of the client, and it is the client who chooses the lawyer; ${ }^{27}$ yet it is the lawyer who acts as a friend in the relation. And as a final contrast to natural friendship, the usual motive for agreeing or refusing to provide legal services is money. Indeed, when we speak of the lawyer's right to represent whomever he wishes, we are usually defending his moral title to represent whoever pays.

But recall that the concept of legal friendship was introduced to answer the argument that the lawyer is morally reprehensible to the extent that he lavishes undue concern on some particular person. The concept of friendship explains how it can be that a particular person may rightfully receive more than his share of care from another: he can receive that care if he receives it as an act of friendship. Although in natural friendship I emphasized the freedom to bestow, surely that freedom must imply a freedom to receive that extra measure of care. And it is the right of the client to receive such an extra measure of care (without regard, that is, to considerations of efficiency or fairness) as much as the lawyer's right to give it, that I have been trying to explicate. Thus, the fact that the care in legal friendship systematically runs all one way does not impair the argument.

Yet the unease persists. Is it that while I have shown that the lawyer has a right to help the "unworthy" client, I have not shown that whenever the lawyer exercises this right he does something which is morally worthy, entitling him to self-respect? I may have shown that the law is obliged to allow the "unworthy" client to seek legal help and the lawyer to give it. But have I also shown that every lawyer who avails himself of this legal right (his and the client's legal right) performs a morally worthy function? Can a good lawyer be a good person?

The lawyer acts morally because he helps to preserve and express the autonomy of his client vis-à-vis the legal system. It is not just that the lawyer helps his client accomplish a particular lawful purpose. Pornography may be legal, but it hardly follows that I perform a morally

27. The lawyer is generally free to decline to serve for any or no reason. But excn that freedom is qualified; there will be times when there may be a duty to scrve, as when a court appoints the lawyer to serve or when his declining may leave a person unrepresented. See pp. 1078-79, 1086-87 infra. 
worthy function if I lend money or artistic talent to help the pornographer flourish in the exercise of this right. What is special about legal counsel is that whatever else may stop the pornographer's enterprise, he should not be stopped because he mistakenly believes there is a legal impediment. There is no wrong if a venture fails for lack of talent or lack of money-no one's rights have been violated. But rights are violated if, through ignorance or misinformation about the law, an individual refrains from pursuing a wholly lawful purpose. Therefore, to assist others in understanding and realizing their legal rights is always morally, worthy. Moreover, the legal system, by instituting the role of the legal friend, not only assures what it in justice must-the due liberty of each citizen before the law-but does it by creating an institution which exemplifies, at least in a unilateral sense, the ideal of personal relations of trust and personal care which (as in natural friendship) are good in themselves.

Perhaps the unease has another source. The lawyer does work for pay. Is there not something odd about analogizing the lawyer's role to friendship when in fact his so-called friendship must usually be bought? If the lawyer is a public purveyor of goods, is not the lawyerclient relationship like that underlying any commercial transaction? My answer is "No." The lawyer and doctor have obligations to the client or patient beyond those of other economic agents. A grocer may refuse to give food to a customer when it becomes apparent that the customer does not have the money to pay for it. But the lawyer and doctor may not refuse to give additional care to an individual who cannot pay for it if withdrawal of their services would prejudice that individual. ${ }^{28}$ Their duty to the client or patient to whom they have made an initial commitment transcends the conventional quid pro quo of the marketplace. It is undeniable that money is usually what cements the lawyer-client relationship. But the content of the relation is determined by the client's needs, just as friendship is a response to another's needs. It is not determined, as are simple economic relationships, by the mere coincidence of a willingness to sell and a willingness to buy. So the fact that the lawyer works for pay does not seriously undermine the friendship analogy.

\section{Institutional Clients}

Another possible objection to my analysis concerns the lawyer in government or the lawyer for a corporation. My model posits a duty

28. See ABA Comm. on Professional Erhics, Opinions 56 (1967) (Informal Opinion No. 334); ABA Code of Professional Responsibility EC 2-31, 2-32. Compare id. DR 2-110 (C)(1)(f) with ial. DR 2-110(A)(2). 
of exclusive concern (within the law) for the interests of the client. This might be said to be inappropriate in the corporate area because larger economic power entails larger social obligations, and because the idea of friendship, even legal friendship, seems peculiarly farfetched in such an impersonal context. After all, corporations and other institutions, unlike persons, are creatures of the state. Thus, the pursuit of their interests would seem to be especially subject to the claims of the public good. But corporations and other institutions are only formal arrangements of real persons pursuing their real interests. If the law allows real persons to pursue their interests in these complex forms, then why are they not entitled to loyal legal assistance, "legal friendship," in this exercise of their autonomy just as much as if they pursued their interests in simple arrangements and associations?

The real problem in these cases is that the definition of the client is complicated and elusive. The fundamental concepts remain the same, but we must answer a question which so far we could treat as straightforward: Who is the client? It is the corporation. But because the corporation is an institutional entity, institutional considerations enter into both the definition of the entity to whom the loyalty is owed and the substance of that loyalty. This is dramatically so in the case of a government lawyer, since his client might be thought to be the government of the United States, or the people of the United States, mediated by an intricate political and institutional framework. So it is said that a United States attorney is interested (unlike an ordinary lawyer) not only in winning his case but also in seeing that "justice is done," because his client's interests are served only if justice is done. Since more and more lawyers have only institutional clients, the introduction of institutional concerns into the definition of the representational obligation is virtually pervasive. From this some would conclude that my argument is inappropriate or at least anachronistic. I insist that my analogy is the correct one, that it is applicable to the institutional client, but that it must be combined in a complicated though wholly coherent way with other arguments about who one's client is and how that client's interests are to be identified.

\section{The Two Criticisms and the Friendship Analogy}

\section{A. The Choice of Clients: The Question of Distribution}

It is time to apply the concept of legal friendship to the first of the two criticisms with which this essay began: that the lawyer's ethic of loyalty to his client and his willingness to pick clients for any and every reason (usually, however, for money) result in a maldistribution 
of a scarce resource, the aid of counsel. It is this criticism which the lawyer shares with the doctor. The preceding sections demonstrated at least this much: that legal counsel-like medical care-must be considered a good, and that he who provides it does a useful thing. But this first criticism in no way questions that conclusion. On the contrary, precisely because medical care and legal counsel are benefits to those who receive them, the critic blames the individual doctor or lawyer for not bestowing his skills in the way which best meets the social need. The notion of legal friendship helps us respond to this criticism.

The lawyer-client relation is a personal relation, and legal counsel is a personal service. This explains directly why, once the relation has been contracted, considerations of efficiency or fair distribution cannot be allowed to weaken it. The relation itself is not a creature of social expediency (though social circumstances provide the occasion for it); it is the creature of moral right, and therefore expediency may not compromise the nature of the relation. This is true in medicine because the human need creates a relation of dependence which it would be a betrayal to compromise. In the lawyer-client relation, the argument is more complex but supports the same conclusion. The relation must exist in order to realize the client's rights against society, to preserve that measure of autonomy which social regulation must allow the individual. But to allow social considerations-even social regulations-to limit and compromise what by hypothesis is an entailment of the original grant of right to the individual is to take away with the left hand what was given with the right. Once the relation has been taken up, it is the client's needs which hold the reinslegally and morally.

If I have a client with legal needs, then neither another person with greater needs nor a court should be able to compel or morally oblige me to compromise my care for those needs. To hold differently would apply the concept of battlefield emergency care (triage) to the area of regular legal service. But doctors do not operate that way and neither should lawyers. For it is just the point about emergencies and wars that they create special, brutal, and depersonalized relations which civilization, by its very essence, must keep from becoming the general rule of social life. ${ }^{29}$

So much for the integrity of the relation once it has taken hold. But what of the initial choice of client? Must we not give some thought to efficiency and relative need at least at the outset, and does this not

29. Fried, supra note 9, at 245. 
run counter to the picture of purely discretionary choice implicit in the notion of friendship? The question is difficult, but before considering its difficulties we should note that the preceding argumentation has surely limited its impact. We can now affirm that whatever the answer to this question, the individual lawyer does a morally worthy thing whomever he serves and, moreover, is bound to follow through once he has begun to serve. In this he is like the doctor. So if there is fault here it is a limited fault. What would be required for a lawyer to immunize himself more fully from criticism that he is unjust in his allocation of care? Each lawyer would have to consider at the outset of his career and during that career where the greatest need for his particular legal talents lies. He would then have to allocate himself to that area of greatest need. Surely there is nothing wrong in doing this (so long as loyalty to relations already undertaken is not compromised); but is a lawyer morally at fault if he does not lead his life in this way? It is at this point too that the metaphor of friendship and the concept of self as developed above suggest the response. But this time they will be viewed from another perspectivethe lawyer's as opposed to the client's rights and liberties.

Must the lawyer expend his efforts where they will do the most good, rather than where they will draw the largest fee, provide the most excitement, prove most flattering to his vanity, whatever? Why must he? If the answer is that he must because it will produce the most good, then we are saying to the lawyer that he is merely a scarce resource. But a person is not a resource. He is not bound to lead his life as if he were managing a business on behalf of an impersonal body of stockholders called human society. It is this monstrous conception against which I argued earlier. Justice is not all; we are entitled to reserve a portion of our concern and bestow it where we will. We may bestow it entirely at our discretion as in the case of friendship, or we may bestow it at what I would call "constrained discretion" in the choice and exercise of a profession. That every exercise of the profession is morally worthwhile is already a great deal to the lawyer's credit. Just as the principle of liberty leaves one morally free to choose a profession according to inclination, so within the profession it leaves one free to organize his life according to inclination. The lawyer's libertymoral liberty-to take up what kind of practice he chooses and to take up or decline what clients he will is an aspect of the moral liberty of self to enter into personal relations freely.

I would not carry this idea through to the bitter end. It has always been accepted, for instance, that a court may appoint an available lawyer to represent a criminal defendant who cannot otherwise find 
counsel. Indeed, I would be happy to acknowledge the existence of some moral duty to represent any client whose needs fit one's particular capacities and who cannot otherwise find counsel. This is not a large qualification to the general liberty I proclaim. The obligation is, and must remain, exceptional; it cannot become a kind of general conscription of the particular lawyer involved. And the obligation cannot compromise duties to existing clients. Furthermore, I would argue that this kind of representation should always be compensated-the duty to the client who cannot afford representation is initially a duty of society, not of the individual lawyer. I go this far for a number of reasons. If the representation is properly compensated, then the very need to appoint a lawyer will be exceptional, an anomaly arising in one of two ways: a fortuitous perturbation in the law of supply and demand or a general, if not concerted, professional boycott of this particular client. If the first is the reason, then the lifetime imposition on any one lawyer will be slight indeed. If it is the second, then the assertion of a duty, oddly enough, serves to express and strengthen the principle of the lawyer's independence. For the moral position of the lawyer rests on the claim that he takes up his client's interests irrespective of their merits. ${ }^{30}$ By accepting from time to time the duty to represent the undesirable, he affirms this independence.

But surely I must admit that the need for legal representation far exceeds what such an unstructured, largely individualistic system could supply. Are there not vast numbers of needy people with a variety of legal problems who will never seek us out, but must be sought out? And what of the general responsibility that just laws be passed and justly administered? These are the obligations which the traditional conception of the lawyer, with his overriding loyalty to the paying client, is thought to leave unmet. At this point I yield no further. If the lawyer is really to be impressed to serve these admitted social needs, then his independence and discretion disappear, and he does indeed become a public resource cut up and disposed of by the public's needs. There would be no justice to such a conception. If there are really not enough lawyers to care for the needs of the poor, then it is grossly unfair to conscript the legal profession to fill those needs. If the

30. Carried further, this argument would hold that, as to clients who are within his area of competence, are able to pay his fee, and create no conflict with existing clients, a doctor or Iawyer is perfectly justified in taking whoever happens to be next in the qucue in his waiting room. Places in the queue may be determined by luck, the price system, or even some bureaucratic method of assignment. The doctor or lawyer does no wrong if he chooses not to concern himself with how the queue was formed. For a more detailed discussion of the moral significance of queuing, see C. FrIED, supra note 10, at 132-37. 
obligation is one of justice, it is an obligation of society as a whole. It is cheap and hypocritical for society to be unwilling to pay the necessary lawyers from the tax revenues of all, and then to claim that individual lawyers are morally at fault for not choosing to work for free. In fact, as provision of legal services has come to be seen as necessary to ensure justice, society has indeed hired lawyers in an effort to meet that need.

Finally, I agree that the lawyer has a moral obligation to work for the establishment of just institutions generally, but entirely the wrong kind of conclusions have been drawn from this. Some of the more ecstatic critics have put forward the lawyer as some kind of anointed priest of justice-a high priest whose cleaving to the traditional conception of the lawyer's role opens him to the charge of apostasy. ${ }^{31}$ But this is wrong. In a democratic society, justice has no anointed priests. Every citizen has the same duty to work for the establishment of just institutions, ${ }^{32}$ and the lawyer has no special moral responsibilities in that regard. To be sure, the lawyer like any citizen must use all his knowledge and talent to fulfill that general duty of citizenship, and this may mean that there are special perspectives and opportunities for him. ${ }^{33}$

\section{B. The Choice of Means}

More difficult problems are posed by the conflict between the interests of the client and the interests of some other concrete and specified person to whom the client stands in opposition. How does my friendship analogy help to resolve the conflict which a lawyer must feel if his client asks him to lie, to oppress, or to conceal-to do something which is either illegal or felt by the lawyer to be immoral?

\section{Staying Within the Law}

I have defined the lawyer as a client's legal friend, as the person whose role it is to insure the client's autonomy within the law. Although I have indicated that the exercise of that autonomy is not always consonant with the public interest, it does not at all follow that the exercise of that autonomy, therefore, must also violate the law. If the legal system is itself sensitive to moral claims, sensitive to the rights of individuals, it must at times allow that autonomy to be exercised in ways that do not further the public interest. Thus, the

31. See, e.g., M. GreEN, supra note 1, at 268-72.

32. See J. RawLs, supra note 24, at 333-91.

33. See abA Code of Professional Responsibility Canon 8. 
principle that the lawyer must scrupulously contain his assistance and advocacy within the dictates of the law seems to me perfectly consistent with my view of the lawyer as the client's friend, who maintains the client's interests even against the interests of society.

To be sure, there may have been and may still be situations where the law grossly violates what morality defines as individual rights; and there have been lawyers who have stood ready to defy such laws in order to further their client's rights-the rights which the law should, but did not, recognize. Whatever might be said about those cases, the lawyer's conduct in them travels outside the bounds of legal friendship and becomes political friendship, political agitation, or friendship tout court. But that is not the case I am examining. The moral claims which a client has on his lawyer can be fully exhausted though that lawyer contains his advocacy strictly within the limits of the law.

A critic who fails to see the importance of the lawyer's moral status in assisting the autonomy of his client, may also be inclined to complain that the constraints of the law restrain his advocacy of truly just causes too much. Such a critic has things wrong at both ends. Just as it is false to argue that the lawyer is morally reprehensible if he furthers the interests of some clients and not others or some purposes and not others, so it is false to assume that the lawyer fails to have the proper zeal if he does for his client only what the law allows. The distinction between the role of the lawyer as a personal adviser and that of the lawyer as a citizen and member of the community should be quite clear. It is by controlling what the law is and by varying the interests that clients may lawfully pursue that social policy should be effectuated; it is not by deforming the role of the lawyer as the client's legal friend and asking him to curb his advocacy in that relationship.

This explains why in a reasonably just system which properly commands the lawyer's loyalty, he must confine his advocacy to what the rules of advocacy permit. He may not counsel his client to commit a crime, nor to destroy evidence, nor to perjure himself on the witness stand. Of course, here as elsewhere there will be borderline problems. It may not be a crime to lie to the judge who has asked the improper and prejudicial question of the defense attorney, but the implicit or quasi-official rules defining the limits of the lawyer's advocacy may nonetheless forbid this. Nothing in my model should discourage the lawyer from observing such limits scrupulously.

A very difficult question would arise if the law imposed upon the lawyer an obligation first to seek and then to betray his client's trust, an obligation to do that which seems outrageous and unjust. I do not mean to say that the resolution of this question would be easy, but my 
analysis at least clearly locates the area in which a resolution should be sought. For such laws, if they are to be opposed, ought to be opposed as are other unjust laws, and not because the lawyer is in general entitled to travel outside the constraints of the law in protecting his client's interests. Maybe in such a dilemma a conscientious lawyer would keep his client's confidence as would a priest or a natural friend; but if conscientiousness requires this, it requires it as an act of disobedience and resistance to an unjust law, rather than as a necessary entailment of some extreme view of the lawyer's general role.

\section{Immoral Means}

I come to what seems to me one of the most difficult dilemmas of the lawyer's role. It is illustrated by the lawyer who is asked to press the unfair claim, to humiliate a witness, to participate in a distasteful or dishonorable scheme. I am assuming that in none of these situations does the lawyer do anything which is illegal or which violates the ethical canons of his profession; the dilemma arises if he acts in a way which seems to him personally dishonorable, but there are no sanctions-legal or professional-which he need fear.

This set of issues is difficult because it calls on the same principles which provide the justification for the lawyer's or the friend's exertions on behalf of the person with whom he maintains a personal relation. Only now the personal relation is one not of benefit but of harm. In meeting the first criticism, I was able to insist on the right of the lawyer as friend to give this extra weight to the interests of his client when the only competing claims were the general claims of the abstract collectivity. But here we have a specific victim as well as a specific beneficiary. The relation to the person whom we deceive or abuse is just as concrete and human, just as personal, as to the friend whom we help.

It is not open to us to justify this kind of harm by claiming that personal relations must be chosen, not thrust upon us. Personal relations are indeed typically chosen. If mere proximity could place on us the obligations of friendship, then there would soon be nothing left of our freedom to bestow an extra measure of care over and above what humanity can justly claim. But there is a personal relation when we inflict intentional harm; the fact that it is intentional reaches out and particularizes the victim. "Who is my neighbor?" is a legitimate question when affirmative aid is in question; it is quite out of order in respect to the injunction "Do not harm your neighbor." Lying, stealing, degrading, inflicting pain and injury are personal relations too. They are not like failing to benefit, and for that reason they are 
laid under a correspondingly stricter regime than abstract harms to the collectivity. ${ }^{34}$ If I claim respect for my own concrete particularity, I must accord that respect to others. Therefore, what pinches here is the fact that the lawyer's personal engagement with the client is urging him to do that to his adversary which the very principles of personal engagement urge that he not do to anyone.

It is not wrong but somewhat lame to argue that the lawyer like the client has autonomy. From this argument it follows that the lawyer who is asked to do something personally distasteful or immoral (though perfectly legal) should be free either to decline to enter into the relationship of "legal friendship" or to terminate it..$^{35}$ And if the client can find a lawyer to do the morally nasty but legally permissible thing for him, then all is well-the complexities of the law have not succeeded in thwarting an exercise of autonomy which the law was not entitled to thwart. So long as the first lawyer is reasonably convinced that another lawyer can be found, I cannot see why he is less free to decline the morally repugnant case than he is the boring or poorly paid case. True, but lame, for one wants to know not whether one may refuse to do the dirty deed, but whether one is morally bound to refuse-bound to refuse even if he is the last lawyer in town and no one else will bail him out of his moral conundrum.

If personal integrity lies at the foundation of the lawyer's right to treat his client as a friend, then surely consideration for personal integrity-his own and others'-must limit what he can do in friendship. Consideration for personal integrity forbids me to lie, cheat, or humiliate, whether in my own interests or those of a friend, so surely they prohibit such conduct on behalf of a client, one's legal friend. This is the general truth, but it must be made more particular if it is to do service here. For there is an opposing consideration. Remember, the lawyer's special kind of friendship is occasioned by the right of

34. This point is discussed in detail in Fricd, Right and Wrong-Preliminary Considerations, 5 J. LeGal STud. (June, 1976; forthcoming). The notion that abstention from harming particular persons is a special kind of duty is expressed in Ross's concept of nonmaleficence. See W. Ross, supra note 15 , at 21-22.

35. DR 2-110(B)(I) of the Code of Professional Responsibility makes withdrawal mandatory if the attorncy "knows or it is obvious that his clicnt is bringing the legal action, conducting the defense, or asserting a position in the litigation, or is otherwisc having steps taken for him, merely for the purpose of harassing or maliciously injuring any person." DR $2-110(C)(1)(c)$ and (l)(d) permit a lawyer to scek withdrawal if the client either "[i]nsists that the lawyer pursue a course of conduct that is illegal or that is prohibited under the Disciplinary Rules" or "[b]y other conduct renders it umreasonably difficult for the lawyer to carry out his employment effectively." For an argument that an attorncy should make his own moral judgments about whether and how to represent clients, see M. Greex, supra notc 1, at 268-89. See also J. Auerbach, supra note 1, at 279.82. 
the client to exercise his full measure of autonomy within the law. This suggests that one must not transfer uncritically the whole range of personal moral scruples into the arena of legal friendship. After all, not only would I not lie or steal for myself or my friends, I probably also would not pursue socially noxious schemes, foreclose on widows or orphans, or assist in the avoidance of just punishment. So we must be careful lest the whole argument unravel on us at this point.

Balance and structure are restored if we distinguish between kinds of moral scruples. Think of the soldier. If he is a citizen of a just state, where foreign policy decisions are made in a democratic way, he may well believe that it is not up to him to question whether the war he fights is a just war. But he is personally bound not to fire dum-dum bullets, not to inflict intentional injury on civilians, and not to abuse prisoners. These are personal wrongs, wrongs done by his person to the person of the victim. ${ }^{36}$ So also, the lawyer must distinguish between wrongs that a reasonably just legal system permits to be worked by its rules and wrongs which the lawyer personally commits. Now I do not offer this as a rule which is tight enough to resolve all borderline questions of judgment. We must recognize that the border is precisely the place of friction between competing moral principles. Indeed, it is unreasonable to expect moral arguments to dispense wholly with the need for prudence and judgment.

Consider the difference between humiliating a witness or lying to the judge on one hand, and, on the other hand, asserting the statute of limitations or the lack of a written memorandum to defeat what you know to be a just claim against your client. In the latter case, if an injustice is worked, it is worked because the legal system not only permits it, but also defines the terms and modes of operation. Legal institutions have created the occasion for your act. What you do is not personal; it is a formal, legally-defined act. But the moral quality of lying or abuse obtains both without and within the context of the law. Therefore, my general notion is that a lawyer is morally entitled to act in this formal, representative way even if the result is an injustice, because the legal system which authorizes both the injustice (e.g., the result following the plea of the statute of limitations) and the formal gesture for working it insulates him from personal moral responsibility. I would distinguish between the lawyer's own wrong and the wrong of the system used to advantage by the client.

The clearest case is a lawyer who calls to the attention of the court a controlling legal precedent or statute which establishes his client's

36. See Nagel, War and Massacre, I Philosophy \& Pun. AfF. 123, 133-34, 136 (1972); Fried, supra note 34 . 
position even though that position is an unjust one. (I assume throughout, however, that this unjust law is part of a generally just and decent system. I am not considering at all the moral dilemmas of a lawyer in Nazi Germany or Soviet Russia.) Why are we inclined to absolve him of personal moral responsibility for the result he accomplishes? I assert it is because the wrong is wholly institutional; it is a wrong which does not exist and has no meaning outside the legal framework. The only thing preventing the client from doing this for himself is his lack of knowledge of the law or his lack of authority to operate the levers of the law in official proceedings. It is to supply that lack of knowledge or of formal capacity that the lawyer is in general authorized to act; and the levers he pulls are all legal levers.

Now contrast this to the lawyer who lies to an opposing party in a negotiation. I assume that (except in extreme cases akin to self-defense) an important lie with harmful consequences is an offense to the victim's integrity as a rational moral being, and thus the liar affirms a principle which denigrates his own moral status. ${ }^{37}$ Every speech act invites belief, and so every lie is a betrayal. However, may a lawyer lie in his representative capacity? It is precisely my point that a man cannot lie just in his representative capacity; it is like stabbing someone in the back "just" in a representative capacity. The injury and betrayal are not worked by the legal process, but by an act which is generally harmful quite apart from the legal context in which it occurs.

There is an important class of cases which might be termed "lying in a representative capacity." An example is the lawyer presenting to the court a statement by another that he knows to be a lie, as when he puts a perjurious client-defendant on the stand. There is dispute as to whether and when the positive law of professional responsibility permits this, ${ }^{38}$ but clearly in such instances it is not the lawyer who is lying. He is like a letter carrier who delivers the falsehood. Whether he is free to do that is more a matter of legal than personal ethics.

A test that might make the distinction I offer more palpable is this: How would it be if it were known in advance that lawyers would balk at the practice under consideration? Would it not be intolerable if it were known that lawyers would not plead the defense of the Statute of Frauds or of the statute of limitations? And would it not be quite

37. Here I follow Augustine, Lying, in Treatises on Various Subjects (R. Deferrari cd. 1952), and I. Kant, The Metaphysical Principles of Virtue 90-93 (J. Ellington trans. 1964).

38. Compare M. Fremoman, supra note 7, at 27-41 with Noonan, The Purposes of Advocacy and the Limits of Confidentiality, 64 Mich. L. REv. 1485 (1966). 
all right if it were known in advance that you cannot get a lawyer to lie for you, though he may perhaps put you on the stand to lie in your own defense?

A more difficult case to locate in the moral landscape is abusive and demeaning cross-examination of a complaining witness. Presumably, positive law and the canons of ethics restrict this type of conduct, but enforcement may be lax or interpretation by a trial judge permissive. So the question arises: What is the lawyer morally free to do? Here again I urge the distinction between exposing a witness to the skepticism and scrutiny envisaged by the law and engaging in a personal attack on the witness. The latter is a harm which the lawyer happens to inflict in court, but it is a harm quite apart from the institutional legal context. It is perhaps just a matter of style or tone, but the crucial point is that the probing must not imply that the lawyer believes the witness is unworthy of respect.

The lawyer is not morally entitled, therefore, to engage his own person in doing personal harm to another, though he may exploit the system for his client even if the system consequently works injustice. He may, but must he? This is the final issue to confront. Since he may, he also need not if there is anyone else who will do it. Only if there is no one else does the agony become acute. If there is an obligation in that case, it is an institutional obligation that has devolved upon him to take up a case, to make arguments when it is morally permissible but personally repugnant to him to do so. Once again, the inquiry is moral, for if the law enjoins an obligation against conscience, a lawyer, like any conscientious person, must refuse and pay the price.

The obligation of an available lawyer to accept appointment to defend an accused is clear. Any moral scruples about the proposition that no man should be accused and punished without counsel are not morally well-founded. The proposition is intended to enhance the autonomy of individuals within the law. But if you are the last lawyer in town, is there a moral obligation to help the finance company foreclose on the widow's refrigerator? If the client pursues the foreclosure in order to establish a legal right of some significance, I do not flinch from the conclusion that the lawyer is bound to urge this right. So also if the finance company cannot foreclose because of an ideological boycott by the local bar. But if all the other lawyers happen to be on vacation and the case means no more to the finance company than the resale value of one more used refrigerator, common sense says the lawyer can say no. One should be able to distinguish between establishing a legal right and being a $\operatorname{cog}$ in a routine, repetitive 
business operation, part of which just happens to play itself out in court.

\section{Conclusion}

I do not imagine that what $I$ have said provides an algorithm for resolving some of these perennial difficulties. Rather, what I am proposing is a general way of looking at the problem, a way of understanding not so much the difficult borderline cases as the central and clear ones, in the hope that the principles we can there discern will illuminate our necessarily approximate and prudential quest for resolution on the borderline. The notion of the lawyer as the client's legal friend, whatever its limitations and difficulties, does account for a kind of callousness toward society and exclusivity in the service of the client which otherwise seem quite mysterious. It justifies a kind of scheming which we would deplore on the part of a lay person dealing with another lay person-even if he were acting on behalf of a friend.

But these special indulgences apply only as a lawyer assists his client in his legal business. I do not owe my client my political assistance. I do not have to espouse his cause when I act as a citizen. Indeed, it is one of the most repellent features of the American legal professionone against which the barrister-solicitor split has to some extent guarded the English profession-that many lawyers really feel that they are totally bought by their clients, that they must identify with their clients' interests far beyond the special purpose of advising them and operating the legal system for them. The defendants' antitrust lawyer or defendants' food and drug lawyer who writes articles, gives speeches, and pontificates generally about the evils of regulation may believe these things, but too often he does so because it is good for business or because he thinks that such conduct is what good representation requires. ${ }^{30}$ In general, I think it deplorable that lawyers have specialized

39. The implications of this idea are particularly important for the so-called Washington lawyer (wherever he might be) who is hired to represent his client before agencies and legislatures contemplating new law. This may put us on one of the borderlines $I$ do not pretend to resolve definitively, yet I think we can get an idea of how to think about these cases too. To the extent that such representation involves participation in a formal procecding in which laws or regulations are drafted and technical competence is required, the task is closer to the traditional task of the lawyer as I have sketched it, and the legal friend concept is more appropriate. To the extent that the representation involves (wholly lawful) deployment of political pressures, inducements, and considerations, it is closer to being political action, and thus to requiring the kind of overriding concern for the common good that should motivate all political actors. Certainly it is absurd that a man should seck to be insulated from moral judgment of his accomplishments as a political string-puller or publicist by the defense that he was only doing it for money. 
not only in terms of subject matter-that may or may not be a good thing-but in terms of plaintiffs or defendants, in terms of the position that they represent. ${ }^{40}$

There is a related point which cuts very much in the opposite direction. It is no part of my thesis that the client is not morally bound to avoid lying to the court, to pay a just debt even though it is barred by the statute of limitations, to treat an opposite party in a negotiation with humanity and consideration for his needs and vulnerability, or to help the effectuation of policies aimed at the common good. Further, it is no part of my argument to hold that a lawyer must assume that the client is not a decent, moral person, has no desire to fulfill his moral obligations, and is asking only what is the minimum that he must do to stay within the law. On the contrary, to assume this about anyone is itself a form of immorality because it is a form of disrespect between persons. Thus in very many situations a lawyer will be advising a client who wants to effectuate his purposes within the law, to be sure, but who also wants to behave as a decent, moral person. It would be absurd to contend that the lawyer must abstain from giving advice that takes account of the client's moral duties and his presumed desire to fulfill them. Indeed, in these situations the lawyer experiences the very special satisfaction of assisting the client not only to realize his autonomy within the law, but also to realize his status as a moral being. I want to make very clear that my conception of the lawyer's role in no way disentitles the lawyer from experiencing this satisfaction. Rather, it has been my purpose to explicate the less obvious point that there is a vocation and a satisfaction even in helping Shylock obtain his pound of flesh or in bringing about the acquittal of a guilty man. ${ }^{41}$

Finally, I would like to return to the charge that the morality of role and personal relationship I offer here is almost certain to lead to the diversion of legal services from areas of greatest need. It is just my point, of course, that when we fulfill the office of friend-legal, medical, or friend tout court-we do right, and thus it would be a great wrong to place us under a general regime of always doing what will "do the most good." What I affirm, therefore, is the moral liberty of a lawyer to make his life out of what personal scraps and shards of

40. In England barristers are regularly hired by the government in all manner of litigation, thereby accomplishing the many-sidedness I call for here. See Q. JoHNSTONE \& D. Horson, Lawyers AND Their Work 374-75 (1967). Why shouid this not be done in the United States? Perhaps there is fear that this might simply become the occasion for a suspect form of patronage.

41. This point is due to Albert Sacks and Richard Stewart. 
motivation his inclination and character suggest: idealism, greed, curiosity, love of luxury, love of travel, a need for adventure or repose; only so long as these lead him to give wise and faithful counsel. It is the task of the social system as a whole, and of all its citizens, to work for the conditions under which everyone will benefit in fair measure from the performance of doctors, lawyers, teachers, and musicians. But I would not see the integrity of these roles undermined in order that the millennium might come sooner. After all, it may never come, and then what would we be left with? 